\title{
Determination of malnutrition status in palliative care patients
}

\section{Palyatif bakım hastalarında yetersiz beslenme durumunun belirlenmesi}

\author{
Derya Bıçak Ayık1, @Zeliha Büyükbayram¹, @Gülbeyaz Can² \\ ${ }^{1}$ Department of Nursing, Siirt University Faculty of Health Sciences, Siirt, Turkey \\ ${ }^{2}$ Istanbul University-Cerrahpaşa, Department of Medical Nursing, Florence Nightingale Faculty of Nursing, Istanbul, Turkey
}

Cite this article as/Bu makaleye atıf için: Bıçak Ayık D, Büyükbayram Z, Can G. Determination of malnutrition status in palliative care patients. J Med Palliat Care 2020; 1(3): 64-70.

\begin{abstract}
Aim: The study was carried out in the descriptive form in order to determine the malnutrition status in palliative care patients.

Material and Method: The research was conducted in the palliative care unit of a hospital in the east of Turkey between May 2019 and December 2019. Since the entire population was aimed to be included in the research, 123 palliative care patients were reached without calculating the sample size and using any sampling method. In order to evaluate the nutritional status of the patients, patient introductory information form and Mini Nutritional Assessment Test (MNA) were used. In the evaluation of the data, descriptive statistics, KruskalWallis Test, Chi-Square and Mann-Whitney $\mathrm{U}$ test were used. All the findings were evaluated at $\mathrm{p}<0.05$ significance level.

Results: The mean age of the patients was $71.88 \pm 14.16$, and $51.2 \%$ of them were male, $95.9 \%$ were married, $39.8 \%$ had cancer and $45.5 \%$ were nourished orally. There was a risk of malnutrition in $89.4 \%$ of the patients and malnutrition development risk in $7.3 \%$. The presence of malnutrition was found to be higher in cancer patients compared with Alzheimer's patients, and in those nourished via percutaneous endoscopic gastronomy, nasogastric catheter and total parenteral nutrition compared to the ones nourished orally $(\mathrm{p}<0.05)$.

Conclusion: The results obtained from this study showed that it is very important, in palliative care patients with a high risk of malnutrition development, to follow the nutritional status closely and to arrange nutritional supportive treatment early so that the patients can go through a good process in the last days of their lives.
\end{abstract}

Keywords: Nutrition, patient, malnutrition, palliative care

ÖZ

Amaç: Palyatif bakım hastalarında malnütrisyon durumunu saptamak amacıyla tanımlayıcı olarak gerçekleştirildi.

Gereç ve Yöntem: Araştırma Türkiye’nin doğusunda yer alan bir hastanenin palyatif bakım ünitesinde Mayıs 2019-Aralık 2019 tarihleri arasında gerçekleştirildi. Evrenin tümünün araştırmaya alınması hedeflendiği için örneklem büyüklüğü hesaplaması yapılmayıp herhangi bir örnekleme yöntemi kullanılmadan 123 palyatif bakım hastasına ulaşıldı. Hastaların beslenme durumunu değerlendirilmek için, hasta tanıtıcı bilgi formu, Mini Nütrisyonel Değerlendirme Testi (MNA) kullanıldı. Verilerin değerlendirilmesinde tanımlayıcı istatistikler, ANOVA, Kruskal Wallis Testi, Ki-Kare ve Mann Whitney U testi kullanıldı. Tüm bulgular p $<0,05$ anlamlılık düzeyinde değerlendirildi.

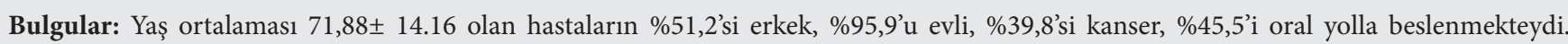
Hastaların \%89,4'ünde malnütrisyon, \%7,3’ünde malnütrisyon gelişme riski olduğu saptandı. Alzheimer hastaları ile kıyaslandığında kanser hastalarında ve beslenme şekli oral olanlar ile kıyaslandığında perkütan endoskopik gastronomi, nazogastrik sonda ve total parenteral beslenme ile beslenenlerde malnütrisyon varlığının daha yüksek olduğu saptandı $(\mathrm{p}<0.05)$.

Sonuç: Bu çalışmadan elde edilen sonuçlar, malnütrisyon gelişme riski yüksek olan palyatif bakım hastalarında, beslenme durumunun yakından takip edilmesinin ve nütrisyon destek tedavisinin erken dönemde düzenlenmesinin hastanın yaşamının son günlerinde iyi bir süreç geçirmesi açısından oldukça önemli olduğunu göstermiştir.

Anahtar Kelimeler: Beslenme, hasta, malnütrisyon, palyatif bakım 


\section{INTRODUCTION}

Palliative care is an approach which aims to increase the quality of life of patients by detecting and treating the symptoms of the patients, who were diagnosed with any life-threatening disease, associated with the disease process in the early period (1). The purpose of palliative care units is to enable terminal period patients to spend their remaining lives more comfortably $(2,3)$. In these patients, adequate and balanced nutrition is one of the basic needs to maintain vital functions. Adequate and balanced nutrition, which is quite effective in protecting health, preventing and treating diseases, can increase the quality of life and sense of well-being, and help alleviate the disturbing symptoms that occur at the end of life (4-6).

Adequate nutrition is important not only to fulfill physiological needs, but also due to its psychological, spiritual, social and cultural benefits for patients and caregivers. Addressing these beneficial aspects of nutrition is of great importance in the palliative environment (5). However, as patients who require palliative care have different diseases, various conditions and prognoses, it is difficult for patients to have a balanced diet due to the negative effects of the disease and treatments $(7,8)$. Some symptoms such as pain, nausea, wounds on the oral mucosa, diarrhea and vomiting while eating may cause impaired nutrition of patients receiving palliative care, and consequently, malnutrition may develop in these patients (8). Malnutrition, which is a significant problem particularly for palliative care units, negatively affects the course of the disease by causing loss of body mass, further decrease of the immune system and insufficiency of organsystem functions, may extend the length of hospital stay, decrease the quality of life and increase the risk of death (810). The risk of developing malnutrition differs depending on the diagnosis, treatment method, age and gender of the patient (8). Specifically with the progression of the disease, patients are generally malnourished, and it is asserted that $20 \%$ of the patients die from the effects of malnutrition rather than the disease itself (4). Therefore, the risk of malnutrition should be identified early in the patient group in the palliative care unit, and early nutritional support should be initiated by providing patients and families with adequate nutritional training and counseling especially in the early period for ideal patient management (3).

The findings of a study reveal that the malnutrition experienced by palliative care patients cannot be limited to only the physical aspect. Malnutrition affects not only the bodies of the patients but also their psychological and social well-being (11). However, there is a lack of literature with respect to this aspect of malnutrition in this patient population $(1,7,12)$. Furthermore, nutritional status, which is very important for palliative care patients, is perceived as a burden of care by healthcare professionals and is usually ignored $(5,7,13,14)$.
Therefore, the main purpose of the study is to specify malnutrition status in palliative care patients, to review the current data related to nutrition and to contribute to the limited current literature.

\section{MATERIAL AND METHOD}

\section{Ethical Aspect of the Study}

This study was approved by the university /local human research ethics committee and all procedures performed in studies involving human participants were in accordance with the ethical standards of the institutional and/or national research committee and with the 1964 Helsinki declaration and its later amendments or comparable ethical standards. Before the research, ethical approval (Permission Granted: 12.03.2019, Decision No: E.4480) and institutional permission from the hospital where the research was conducted were obtained. Verbal and written consent was obtained from the patients included in the study by giving the patients included in the research necessary explanations.

\section{Desing and Sample}

The research was carried out in the descriptive form in the Palliative Care Unit of a hospital in the east of Turkey between May 2019 and December 2019. Since the whole population was aimed to be included in the research, the sample size was not calculated, and no sampling method was used. In the unit, 320 patients received palliative care service between the dates the study was carried out. Because it was not possible to evaluate patients who could not communicate verbally and were unconscious $(n=116)$ and those who got 12 points or higher from the first 6 questions of the MNA scale $(n=81)$ were not included in the study. The study was completed with the participation of 123 palliative care patients. The data were collected by the researcher between the aforementioned dates in the palliative care unit in the patient rooms by using the faceto-face interview method and data collection tools. The interviews took about 15-20 minutes.

\section{Data Collection Tools}

Patient Introductory Survey Form: This diagnostic form, which was prepared by the researcher in line with the literature in order to determine the socio-demographic characteristics, disease characteristics (diagnosis, duration, etc.) and diets of the patients, consists of a total of 10 questions $(1,5,8,14,15)$.

Mini Nutritional Assessment Test (MNA): Developed by Vellas et al in 1997, MNA is a short diagnostic tool used to diagnose the nutritional status of patients staying in care units, care houses and nursing homes for a long time $(16,17)$. This diagnostic tool, whose validity and reliability study has been conducted in different countries and several studies, has been shown to be a valid and reliable screening tool for the identification of nutritional status of the elderly (18-20). MNA consists of 18 questions, three of which are based on anthropometric measurement. 
Using this diagnostic tool, the evaluation of the patient's nutritional adequacy is carried out in two stages: In the first stage, the first 6 questions of MNA are asked to the patient and the patient's score is calculated in line with the patient's responses. In the second stage, if the patient's score is 11 points or below, the total score is calculated by asking the remaining 12 questions; if it is not, the evaluation is terminated because the patient has no risk of malnutrition. Scoring of the screening tool is done over 30 points. The patient's score of 24 and above is considered to be "no risk of malnutrition", 17-23.5 is considered as "risk of malnutrition" or below 17 is considered as "malnutrition" $(6,19,21-23)$.

\section{Statistical Evaluation}

The data were evaluated in the IBM SPSS Statistics Standard Concurrent User V 25 (New York, IBM Corp., USA Armonk) statistical packaged software. Descriptive statistics were stated as percentage (\%), number of units (n), mean \pm standard deviation (X+ $\pm s s)$, median (M), $25^{\text {th }}$ Percentage (Q1), $75^{\text {th }}$ Percentage (Q3). The normal distribution of the data expressing numerical variables were evaluated with Q-Q graphics and Shapiro-Wilk normality test. The homogeneity of the variances was evaluated via Levene's test. In the variables with no normal distribution, two-group comparisons were made with the Mann-Whitney U test. For the normally distributed age variable, intergroup comparison was determined by oneway analysis of variance. For the variables that did not have a normal distribution, intergroup comparisons were performed with Kruskal-Wallis analysis in more than two groups. If there was a difference according to the KruskalWallis analysis result, the multiple comparison test, DunnBonferroni test, was used. The relationship between age and MNA total score was evaluated by Spearman's correlation analysis. In the intergroup comparison of the categorical variables, the exact method of the Fisher ChiSquare test was used in the rxc tables. If there a relationship was found in the chi-square test, the intergroup difference in the categories was determined via Bonferroni corrected two-proportions $\mathrm{z}$ test. $\mathrm{p}<0.05$ was considered statistically significant.

\section{Limitation of the Study}

This study only reflects the patients in the hospital where it was carried out; it cannot be generalized for all the patients.

\section{RESULTS}

When the descriptive characteristics of the patients were evaluated, it was found that $51.2 \%$ of the patients hospitalized in palliative care were male, $95.9 \%$ were married, $52 \%$ were illiterate, $39.8 \%$ were cancer patients, $45.5 \%$ were nourished orally, $13 \%$ were nourished with percutaneous endoscopic gastronomy (PEG), 7.3\% were nourished with a nasogastric catheter (NG) and $34.1 \%$ were nourished via total parenteral nutrition (TPN), and the mean age of the patients was $71.88 \pm 14.16$ (Table 1).

\begin{tabular}{|c|c|c|}
\hline Descriptive Characteristics & $\mathbf{N}$ & $\%$ \\
\hline \multicolumn{3}{|l|}{ Gender } \\
\hline Female & 60 & 48.8 \\
\hline Male & 63 & 51.2 \\
\hline \multicolumn{3}{|l|}{ Marital status } \\
\hline Married & 118 & 95.9 \\
\hline Single & 5 & 4.1 \\
\hline \multicolumn{3}{|l|}{ Educational level } \\
\hline Illiterate & 64 & 52.0 \\
\hline Literate & 20 & 16.3 \\
\hline Primary education & 29 & 23.6 \\
\hline High school & 8 & 6.5 \\
\hline Undergraduate/graduate & 2 & 1.6 \\
\hline \multicolumn{3}{|l|}{ Disease diagnosis } \\
\hline Cancer & 49 & 39.8 \\
\hline Heart failure & 14 & 11.4 \\
\hline Diabetes & 7 & 5.7 \\
\hline Cerebrovascular & 18 & 14.6 \\
\hline Alzheimer & 25 & 20.3 \\
\hline Others & 10 & 8.1 \\
\hline \multicolumn{3}{|l|}{ Disease duration } \\
\hline Less than a year & 42 & 34.1 \\
\hline $1-5$ year & 51 & 41.5 \\
\hline 6-10 year & 15 & 12.2 \\
\hline 11 years and over & 15 & 12.2 \\
\hline \multicolumn{3}{|l|}{ Income status } \\
\hline Poor & 32 & 26.0 \\
\hline Moderate & 86 & 69.9 \\
\hline Well & 5 & 4.1 \\
\hline \multicolumn{3}{|l|}{ Feeding type } \\
\hline Oral & 56 & 45.5 \\
\hline PEG & 16 & 13.0 \\
\hline NG & 9 & 7.3 \\
\hline TPN & 42 & 34.1 \\
\hline Total & 123 & 100.0 \\
\hline \multirow[t]{2}{*}{ Mean current age } & \multicolumn{2}{|c|}{$\mathrm{X}^{-} \pm \mathrm{SD}$} \\
\hline & \multicolumn{2}{|c|}{$71.88 \pm 14.16$} \\
\hline
\end{tabular}

When the nutritional status of the patients was evaluated, it was found that $3.3 \%(n=4)$ of the patients hospitalized in palliative care had no malnutrition risk, $7.3 \%(\mathrm{n}=9)$ had a malnutrition risk and $89.4 \%(\mathrm{n}=110)$ had malnutrition (Figure 1).

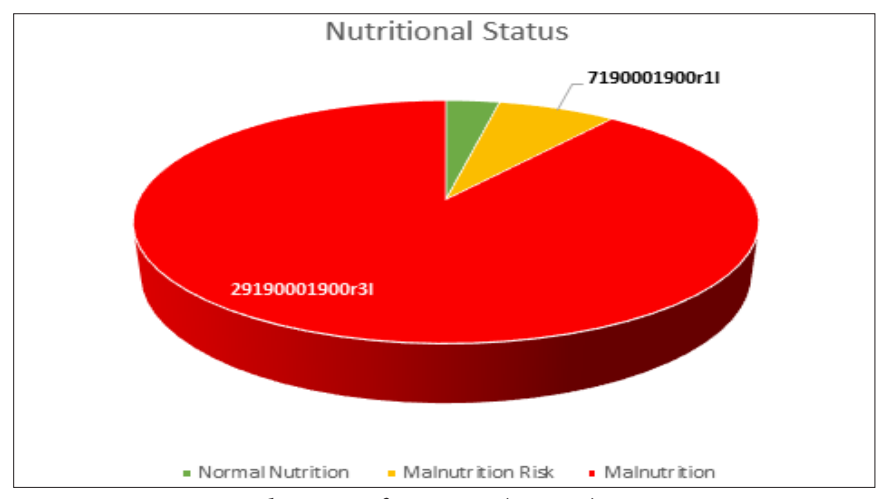

Figure 1. Nutritional status of patients $(n=123)$ 
When we evaluated the effect of patients' individual characteristics on the nutritional status, it was found that patient's age, gender, marital status, educational level, income status and disease diagnosis and duration were not important variables in the development of malnutrition. Besides, the patient's diet was found to play a significant role in the nutritional status. It was discovered that the risk of malnutrition was higher in those nourished orally compared to the TPN group (Table 2). Additionally, there was no statistically significant relationship between age and MNA total by Spearman's Correlation Analysis $($ rho $=-0.15 ; \mathrm{p}=0.11)$.
When we evaluate the effect of patient characteristics on nutritional status according to the percentage value including the MNA score of the patients, it was revealed that patient's age, gender, marital status, educational level, income status and duration of disease were not important variables in malnutrition development, and the patient's diet and diagnosis of the disease played a role $(\mathrm{p}<0.05)$. In the evaluation, it was found that the presence of malnutrition was higher in cancer patients compared to Alzheimer's patients and those nourished with PEG, NGS and TPN compared to those nourished orally (Table 3).

Table 2. Nutrition distribution according to the descriptive characteristics of patients $(\mathrm{N}=123)$

\begin{tabular}{|c|c|c|c|c|c|c|c|c|}
\hline \multirow{2}{*}{ Descriptive Characteristics } & \multicolumn{2}{|c|}{ Normal Nutrition $\mathrm{N}=4$} & \multicolumn{2}{|c|}{ Malnutrition Risk N=9 } & \multicolumn{2}{|c|}{ Malnutrition $\mathrm{N}=110$} & \multicolumn{2}{|c|}{ Test Statistics } \\
\hline & $\mathbf{N}$ & $\%$ & $\mathbf{N}$ & $\%$ & $\mathbf{N}$ & $\%$ & $x^{2}$ & $\mathbf{p}$ \\
\hline Gender & & & & & & & 2.07 & 0.34 \\
\hline Female & 1 & 1.7 & 6 & 10.0 & 53 & 88.3 & & \\
\hline Male & 3 & 4.8 & 3 & 4.8 & 57 & 90.5 & & \\
\hline Marital status & & & & & & & 0.62 & 1.00 \\
\hline Married & 4 & 3.4 & 9 & 7.6 & 105 & 89.0 & & \\
\hline Single & 0 & 0.0 & 0 & 0.0 & 5 & 100.0 & & \\
\hline Educational level & & & & & & & 7.82 & 0.39 \\
\hline Illiterate & 1 & 1.6 & 5 & 7.8 & 58 & 90.6 & & \\
\hline Literate & 0 & 0.0 & 1 & 5.0 & 19 & 95.0 & & \\
\hline Primary education & 3 & 10.3 & 3 & 10.3 & 23 & 79.3 & & \\
\hline High school & 0 & 0.0 & 0 & 0.0 & 8 & 100.0 & & \\
\hline Undergraduate/graduate & 0 & 0.0 & 0 & 0.0 & 2 & 100.0 & & \\
\hline Disease diagnosis & & & & & & & 7.22 & 0.72 \\
\hline Cancer & 3 & 6.1 & 5 & 10.2 & 41 & 83.7 & & \\
\hline Heart failure & 1 & 7.1 & 1 & 7.1 & 12 & 85.7 & & \\
\hline Diabetes & 0 & 0.0 & 1 & 14.3 & 6 & 85.7 & & \\
\hline Cerebrovascular & 0 & 0.0 & 0 & 0.0 & 18 & 100.0 & & \\
\hline Alzheimer & 0 & 0.0 & 1 & 4.0 & 24 & 96.0 & & \\
\hline Others & 0 & 0.0 & 1 & 10.0 & 9 & 90.0 & & \\
\hline Disease duration & & & & & & & 1.28 & 1.00 \\
\hline Less than a year & 1 & 2.4 & 3 & 7.1 & 38 & 90.5 & & \\
\hline $1-5$ year & 2 & 3.9 & 4 & 7.8 & 45 & 88.2 & & \\
\hline 6-10 year & 1 & 6.7 & 1 & 6.7 & 13 & 86.7 & & \\
\hline 11 years and over & 0 & 0.0 & 1 & 6.7 & 14 & 93.3 & & \\
\hline Income status & & & & & & & 3.01 & 0.50 \\
\hline Poor & 0 & 0.0 & 2 & 6.3 & 30 & 93.8 & & \\
\hline Moderate & 4 & 4.7 & 6 & 7.0 & 76 & 88.4 & & \\
\hline Well & 0 & 0.0 & 1 & 20.0 & 4 & 80.0 & & \\
\hline Feeding type & & & & & & & 13.81 & 0.04 \\
\hline Oral & 3 & 5.4 & $9^{\mathrm{a}}$ & 16.1 & $44^{\mathrm{a}}$ & 78.6 & & \\
\hline PEG & 0 & 0.0 & $0^{\mathrm{ab}}$ & 0.0 & $16^{\mathrm{ab}}$ & 100.0 & & \\
\hline NG & 0 & 0.0 & $0^{\mathrm{ab}}$ & 0.0 & $9^{\mathrm{ab}}$ & 100.0 & & \\
\hline TPN & 1 & 2.4 & $0^{\mathrm{b}}$ & 0.0 & $41^{\mathrm{b}}$ & 97.6 & & \\
\hline & $\mathbf{x}^{-}$ & sd & $x^{-}$ & sd & $\mathbf{x}^{-}$ & sd & $\mathbf{F}$ & $\mathbf{p}$ \\
\hline Age & 62.75 & 19.31 & 68.22 & 11.57 & 72.51 & 14.14 & 1.247 & 0.291 \\
\hline
\end{tabular}




\begin{tabular}{|c|c|c|c|c|c|}
\hline \multirow{2}{*}{$\begin{array}{l}\text { Descriptive Characteristics } \\
\text { Gender }\end{array}$} & \multirow[t]{2}{*}{ Median Value } & \multirow[t]{2}{*}{ 25.Percentage Value } & \multirow[t]{2}{*}{ 75.Percentage Value } & \multicolumn{2}{|c|}{ Test Statistics } \\
\hline & & & & $\mathrm{z}=0.877$ & $\mathrm{p}=0.381$ \\
\hline Female & 5.50 & 2.50 & 9.25 & & \\
\hline Male & 4.50 & 2.12 & 7.00 & & \\
\hline Marital status & & & & $\mathrm{z}=0.032$ & $\mathrm{p}=0.974$ \\
\hline Married & 5.50 & 2.50 & 8.00 & & \\
\hline Single & 4.50 & 2.62 & 9.37 & & \\
\hline Educational level & & & & $\mathrm{H}=2.348$ & $\mathrm{p}=0.672$ \\
\hline Illiterate & 5.50 & 2.00 & 8.00 & & \\
\hline Literate & 4.50 & 3.00 & 6.50 & & \\
\hline Primary education & 7.50 & 0.50 & 11.00 & & \\
\hline High school & 3.50 & 1.50 & 5.25 & & \\
\hline Undergraduate/graduate & 4.50 & 3.50 & 5.50 & & \\
\hline Disease diagnosis & & & & $\mathrm{H}=18.540$ & $\mathrm{p}=0.002$ \\
\hline Cancer & $4.75^{\mathrm{ab}}$ & 1.00 & 7.50 & & \\
\hline Heart failure & $4.50^{\mathrm{ab}}$ & 4.00 & 10.00 & & \\
\hline Diabetes & $1.00^{\mathrm{b}}$ & 0.00 & 5.50 & & \\
\hline Cerebrovascular & $4.00^{\mathrm{ab}}$ & 3.87 & 6.375 & & \\
\hline Alzheimer & $6.50^{\mathrm{a}}$ & 1.25 & 10.00 & & \\
\hline Others & $6.40^{\mathrm{ab}}$ & 4.00 & 7.00 & & \\
\hline Disease duration & & & & $\mathrm{H}=5.087$ & $p=0.166$ \\
\hline Less than a year & 6.00 & 4.00 & 8.00 & & \\
\hline $1-5$ year & 3.50 & 1.00 & 9.12 & & \\
\hline $6-10$ year & 7.00 & 1.12 & 9.75 & & \\
\hline 11 years and over & 4.50 & 0.50 & 7.37 & & \\
\hline Income status & & & & $\mathrm{H}=4.077$ & $\mathrm{p}=0.130$ \\
\hline Poor & 6.25 & 3.75 & 8.25 & & \\
\hline Moderate & 4.50 & 1.00 & 8.00 & & \\
\hline Well & 8.00 & 4.50 & 13.37 & & \\
\hline Feeding type & & & & $\mathrm{H}=31.295$ & $\mathrm{p}<0.001$ \\
\hline Oral & $7.25^{\mathrm{a}}$ & 5.50 & 12.00 & & \\
\hline PEG & $1.00^{\mathrm{b}}$ & 0.00 & 4.50 & & \\
\hline NG & $3.00^{\mathrm{b}}$ & 0.50 & 5.87 & & \\
\hline TPN & $4.00^{\mathrm{b}}$ & 1.00 & 6.00 & & \\
\hline
\end{tabular}

\section{DISCUSSION}

Despite recent medical progresses, malnutrition remains an important and quite common problem in developed countries $(24,25)$. Palliative care patients are known to be vulnerable to malnutrition-related outcomes such as prolonged hospital stay, increased risk of falling, admission to high-level care, decrease in physical function, low quality of life, increased risk of lifethreatening complications and mortality (25-27). In the study conducted by Çınar et al. (28) it was determined that $57.4 \%$ of palliative care patients had malnutrition and $27.8 \%$ had a risk of malnutrition. In our study, we showed that malnutrition was an important issue in palliative care patients since $89.43 \%$ of our subjects were found to have malnutrition in terms of nutritional evaluation (Table 2). Besides, it was revealed that diet and malnutrition were related. The risk of malnutrition was found to be higher in those with oral nourishment than in the TPN group. On the other hand, the presence of malnutrition was found higher in those nourished with TPN than the ones with an oral diet (Table 2). The results we obtained from the study were found to comply with the literature $(8,29-32)$.
Malnutrition develops due to decreased dietary intake, increased nutritional requirements or impaired ability to use or absorb nutrients $(30,33)$. When the literature is examined, it was seen that the rate of malnutrition increased with age, $(6,21,23,25)$ and nutritional deficiency in the elderly in the community was found to be around $60 \%$ (31). In our study, it was found that there was no statistically significant difference between the nutritional status and age (Table 3), gender, educational status, marital status, income status, and disease duration according to the MNA scale, however, the malnutrition rate was higher in elderly patients (Table 2 ). In another study conducted with palliative care patients in our country, the malnutrition rate was higher in patients above the age of 90 , but there was no statistically significant relationship between age and nutritional status (31). In a prospective study conducted with elderly cancer patients, patients with low MNA levels were found to have a shorter survival time (34). For this reason, it is necessary to be more careful in terms of malnutrition especially in elderly and patient groups in need of palliative care. 
Malnutrition is common in most patients at an advanced cancer stage (11). Malnutrition in this patient group results from an inflammatory condition that causes anorexia and thus excessive weight loss (32). It is known that anorexia, weight loss and muscle loss, which are called cancer cachexia, are present in $80 \%$ of end-stage cancer patients (11). As cancer patients are reported to experience weight loss together with the diagnosis, malnutrition is very common in this patient group (32). In other studies on malnutrition, it has been observed that the malnutrition risk and incidence of malnutrition are substantially high in cancer patients (35-38). Considering the difference between the diagnosis and nutritional status of the inpatients in the palliative care unit was reviewed in our study, it was found that cancer patients had higher malnutrition levels than patients in the other group and there was a statistically significant difference between the diagnosis of the disease and malnutrition. Malnutrition, which is common in cancer patients, has a great effect on quality of life and survival (39). In a systematic study investigating the effect of various factors on malnutrition in cancer patients, it has been reported that the location of the tumor and the stage of the disease have an effect on malnutrition, therefore, early nutritional screening is important for the course of cancer (40). Balanced and regular nutrition of the patients is important in cancer patients because of the disease itself and/or treatment methods (8). In this respect, nurses should organize the diet lists of cancer patients specifically to the patients under the control of dieticians and follow them.

Malnutrition has medical and economic importance in hospitalized patients (41). Malnutrition causes weaknesssensitivity and/or dependency, worsens the patient's condition, contributes to the development of morbidity, leads to longer hospital stay and decreases quality of life $(25,41)$. Besides, it is also correlated with the worsening prognosis of the underlying diseases and increases the risk of death (25). Early diagnosis can enable earlier intervention, improved results and better quality of life. For this reason, nutritional screening that leads to the determination of etiological factors is a necessary step (25). Nutritional status should be evaluated early and regularly during the treatment via appropriate tools (3). The nurse plays a crucial role in recognizing changes in the patient's condition and managing symptoms that influence the patient's nutrition (1). Healthcare professionals should recognize the risk of malnutrition early in the patients in the palliative care unit and initiate nutritional support early by providing the patients and families with adequate nutritional training and counseling especially in the early period for an ideal patient management $(3,5)$. Effective interactions between the patient, caregivers and healthcare team will also fulfill the specific nutritional needs of each patient by increasing the chances of solving the nutritional problems, therefore, help with improving the quality of life (3).

\section{CONCLUSION}

Inadequate food intake and weight loss are widely observed in patients especially towards the end of life and are perceived as a source of distress for patients and their families. However, the effects of malnutrition are still ignored, and therefore, malnutrition is not considered as a definitive diagnosis. Moreover, malnutrition is rarely documented in medical reports, and its negative effects are not adequately treated in general. The main reason for this ignorance is the inadequate training of physicians and nurses on clinical nutrition and the lack of sensitivity of the hospital personnel towards the problem of malnutrition. Additionally, it is seen that nursing studies focusing on the nutritional problem of palliative care patients are limited. It is recommended to develop models and conduct necessary studies on this issue. Furthermore, it is recommended to determine and frequently review the nutritional levels and requirements of the patients monitored in the palliative care unit by using screening tests, and to provide the patients with nutritional support according to the results obtained.

\section{ETHICAL DECLARATIONS}

Ethics Comittee Approval: Before the research, ethical approval (Permission Granted: 12.03.2019, Decision No: E.4480) and institutional permission from the hospital where the research was conducted were obtained.

Informed Consent: Verbal and written consent was obtained from the patients included in the study by giving the patients included in the research necessary explanations.

Referee Evaluation Process: Externally peer-reviewed.

Conflict of Interest Statement: No conflict of interest was declared by the authors.

Financial Disclosure: The authors declared that this study has received no financial support.

Author Contributions: All of the authors declare that they have all participated in the design, execution, and analysis of the paper, and that they have approved the final version.

\section{REFERENCES}

1. Day T. Managing the nutritional needs of palliative care patients. Br J Nurs Mark Allen Publ 2017; 26: 1151-9.

2. Avc1 D. Are the nutritional NRS-2002 scores of cancer patients at the palliative care center related to inflammation? Bozok Tip Derg 2018; 8: 71-5.

3. Prevost V, Grach M-C. Nutritional support and quality of life in cancer patients undergoing palliative care: Nutritional support in cancer palliative care. Eur J Cancer Care (Engl) 2012; 21: 581-90.

4. Acreman S. Nutrition in palliative care. Br J Community Nurs 2009; 14: 427-31. 
5. Bazzan AJ, Newberg AB, Cho WC, Monti DA. Diet and nutrition in cancer survivorship and palliative care. Evid Based Complement Alternat Med 2013; 2013: 1-12.

6. Çinar H, Kaya Y, Enginyurt Ö. Effects of nutritional status on quality of life in palliative care patients. Bozok Med J 2017; 7: 1-7.

7. Hurlow A. Nutrition and hydration in palliative care. Br J Hosp Med 2019; 80: 78-85.

8. Sancar Bekircan E, Ünlü A. The detection of the relationship between depression and malnutrition in cancer patients. J Tradit Med Complement Ther 2018; 1: 109-14.

9. Lottes Stewart M. Nutrition support protocols and their influence on the delivery of enteral nutrition: a systematic review. Worldviews Evid Based Nurs 2014; 11: 194-9.

10. Tuncer Ö, Bayindir A. Malnutrition approach in the palliative care patients. Klin Tip Aile Hekim 2016 May 30; 8: 11-4.

11. Muir CI, Linklater GT. A qualitative analysis of the nutritional requirements of palliative care patients. J Hum Nutr Diet 2011; 24: 470-8

12. Good P, Richard R, Syrmis W, Jenkins-Marsh S, Stephens J. Medically assisted hydration for adult palliative care patients. Cochrane Database Syst Rev 2014; 4: CD006273.

13. Gillespie L, Raftery A-M. Nutrition in palliative and end-of-life care. Br J Community Nurs 2014; 19: S15-20.

14. Río MI, Shand B, Bonati P, et al. Hydration and nutrition at the end of life: a systematic review of emotional impact, perceptions, and decision-making among patients, family, and health care staff: Perceptions toward hydration and nutrition at the end of life. Psychooncology 2012; 21: 913-21.

15. Hopkinson J, Wright D, Corner J. Exploring the experience of weight loss in people with advanced cancer. J Adv Nurs 2006; 54: 304-12.

16. Skates JJ, Anthony PS. Identifying geriatric malnutrition in nursing practice: The Mini Nutritional Assessment, an evidence, based screening tool. J Gerontol Nurs 2012; 38: 18-27.

17. Muurinen SM, Soini HH, Suominen MH, Saarela RKT, Savikko NM, Pitkälä KH. Vision impairment and nutritional status among older assisted living residents. Arch Gerontol Geriatr 2014; 58: 384-7.

18. Baz S, Ardahan M. Malnutrition in the elderly, nursing approaches. Balıkesir Sağlık Bilim Derg 2016; 5: 147-53.

19. Rubenstein LZ, Harker JO, Salvà A, Guigoz Y, Vellas B. Screening for undernutrition in geriatric practice: developing the shortform mini-nutritional assessment (MNA-SF). J Gerontol A Biol Sci Med Sci 2001; 56: M366-M372.

20.Şahin H, Çiçek B, Yılmaz M, Ongan D, Kaya N, İnanç N Determining nutritional status and quality of life of 65 years and older individuals in Kayseri. Turk J Geriatr 2013; 16: 322-9.

21.Balcı E, Şenol V, Eşel E, Günay O, Elmalı F. The relationship between malnutrition and depression in people aged over 65 years. Türkiye Halk Sağlığ 1 Derg 2012; 10: 37-43.

22. Cohendy R, Rubenstein LZ, Eledjam JJ. The Mini Nutritional Assessment-Short Form for preoperative nutritional evaluation of elderly patients. Aging Clin Exp Res 2001; 13: 293-7.

23. Özgün Başıüyük G, Ayremlou P, Nourı Saeıdlou S, et al. Evaluation of malnutrition among elderly people living in nursing homes by Mini Nutritional Assessment Short Form (MNA-SF) in Turkey. Mædica 2019; 14: 38-44.

24. Bassim CW, Fassil H, Dobbin M, et al. Malnutrition in patients with chronic GVHD. Bone Marrow Transplant 2014; 49: 1300-6.

25. Guyonnet S, Rolland Y. Screening for malnutrition in older people. Clin Geriatr Med 2015; 31: 429-37.

26. Agarwal E, Miller M, Yaxley A, Isenring E. Malnutrition in the elderly: a narrative review. Maturitas 2013; 76: 296-302.
27. Field LB, Hand RK. Differentiating malnutrition screening and assessment: a nutrition care process perspective. J Acad Nutr Diet 2015; 115: 824-8.

28. Çınar H, Kaya Y, Enginyurt Ö. Quality of life in palliative care patients. Turk Klin J Fam Med-Spec Top 2017; 8: 282-6.

29. Aaldriks AA, Maartense E, Le Cessie S, et al. Predictive value of geriatric assessment for patients older than 70 years, treated with chemotherapy. Crit Rev Oncol Hematol 2011; 79: 205-12.

30. Bayır H, Yıldız İ, Erkuran MK, Koçoğlu H. Malnutrition in intensive care patients. Abant Med J 2015; 4: 420-7.

31. Çınar H, Kaya Y, Özyurt N, Çakır L, Ongun A. Assessment of nutritional status in palliative care patients. Klin Tip Aile Hekim 2016; 8: 15-8.

32. Ravasco P. Nutrition in Cancer Patients. J Clin Med. 2019; 8: 1211.

33. Holder H. Nursing management of nutrition in cancer and palliative care. Br J Nurs 2003; 12: 667-74.

34. Bourdel-Marchasson I, Diallo A, Bellera C, et al. One-year mortality in older patients with cancer: development and external validation of an MNA-based prognostic score. PLoS One 2016; 11: e0148523.

35. Cui HY, Zhu MW, Wei JM, Chen W, Yang X, Zhu SN. Changes in nutritional status of patients with different diseases during hospitalization. Zhonghua Wai Ke Za Zhi 2017; 55: 297-302.

36. Fernández ML, Saenz CF, Alonso SU, et al. Malnutrition in patients with cancer; four years experience. Nutr Hosp 2013; 28: 372-81.

37. Shaw C, Fleuret C, Pickard JM, Mohammed K, Black G, Wedlake L. Comparison of a novel, simple nutrition screening tool for adult oncology inpatients and the Malnutrition Screening Tool (MST) against the Patient-Generated Subjective Global Assessment (PGSGA). Support Care Cancer 2015; 23: 47-54.

38.Zhu MW, Wei JM, Chen W, et al. Dynamic investigation of nutritional risk in patients with malignant tumor during hospitalization. Zhonghua Yi Xue Za Zhi 2018; 98: 1093-8.

39. Uster A, Ruefenacht U, Ruehlin M, et al. Influence of a nutritional intervention on dietary intake and quality of life in cancer patients: a randomized controlled trial. Nutrition 2013; 29: 1342-9.

40. Hébuterne X, Lemarié E, Michallet M, de Montreuil CB, Schneider SM, Goldwasser F. Prevalence of malnutrition and current use of nutrition support in patients with cancer. J Parenter Enter Nutr 2014; 38: 196-204.

41. Vonzun N, Rühlin M, Sterchi A. Malnutrition in the era of DRG. Ther Umsch Rev Ther 2014; 71: 185-9. 